\title{
Effects of Houttuynia cordata Extracts of Different Aerial Parts on Antioxidants and Anti-inflammatory
}

\author{
Sung-Gyu Lee and Hyun Kang ${ }^{\dagger}$ \\ Department of Medical Laboratory Science, College of Health Science, Dankook University, \\ Cheonan-si, Chungnam 31116, Korea
}

\begin{abstract}
The current study was carried out to determine the effects of the leaf and root of Houttuynia cordata Thunb on antioxidant and anti-inflammatory. Total polyphenol contents of leaf and root ethanol extracts were found to be 59.32 and $12.07 \mathrm{mg} / \mathrm{g}$, respectively. Also, total flavonoid contents of leaf and root ethanol extracts were found to be 10.85 and $8.55 \mathrm{mg} / \mathrm{g}$, respectively. The $\mathrm{RC}_{50}$ values of $\mathrm{DPPH}$ radical scavenging of leaf and root ethanol extracts were 23.51 and $154.72 \mu \mathrm{g} / \mathrm{mL}$, respectively. The $\mathrm{RC}_{50}$ values of $\mathrm{ABTS}$ radical scavenging of leaf and root ethanol extracts were 35.42 and $233.89 \mu \mathrm{g} / \mathrm{mL}$, respectively. The antioxidant activities in leaf ethanol extracts were higher in root. Also, to confirm anti-inflammatory activity of ethanol extract, we treat leaf and root of Houttuynia cordata Thunb extract on BV-2 cell with LPS. The NO inhibition effects in of Houttuynia cordata Thunb leaf ethanol extracts showed higher values compared with the root ethanol extracts. These results indicate that Houttuynia cordata Thunb ethanol extracts may play a positive role in antioxidant and anti-inflammatory.
\end{abstract}

Key Words: Houttuynia cordata, Leaf, Polyphenol, BV-2, Antioxidant

\begin{abstract}
서 론
지속적인 경제 성장과 소득의 증대에 따라 우리나라 국민들의 평균 수명은 1971년 62.3세에서 2015년 남성이 79세, 여성이 86세로 연장되었다. 경제 성장은 수명뿐만 아니라 만성질환인 생활습관병(lifestyle related disease) 또한 같이 증가시켰으며(Tanaka et al., 2000), 많은 고령층에서 심장질환, 관절염, 요통 및 신경통, 고혈압, 당뇨병, 위장질 환 등과 같은 만성질환을 않고 있는 것으로 알려져 있다. 한편, 노화, 암, 심혈관계 질환 같은 만성질환이 생체의 대사과정에서 발생되는 활성산소류(reactive oxygen species, ROS)에 기인한다고 알려졌다(Wiseman, 1996; Bouayed and
\end{abstract}

Bohn, 2010). ROS는 세포 내 DNA, RNA, 단백질 등과 반 응하여 세포 손상 및 파괴 등을 유발하여(Aischer and Hess, 1993; Chen et al., 2012) 암, 동맥경화, 당뇨병과 같은 다양 한 질병과 노화를 이끌고 특히 다른 장기에 비해 산소의 이용률이 높은 뇌의 경우, 신경세포의 사멸을 유도하여 알 츠하이머병, 파킨슨병, 간질, 뇌졸중 등과 같은 질환을 유 발시킨다(Decker et al., 1992).

이러한 활성산소는 체내에서 존재하는 Superoxide dismutase (SOD), glutathione peroxidase (GPX), catalase (CAT), glutathione reductase, glutathione-S-transferase과 같은 항산화 효소들로 인하여 자연적으로 없어지긴 하지만, 대사과정 에 있어 문제가 발생되거나 염증과 관련된 인체질환이 야 기된다면, 체내에 존재하는 항산화 물질이 고갈되어 효과

* Received: May 3, 2018 / Revised: June 22, 2018 / Accepted: June 25, 2018

†Corresponding author: Hyun Kang. Department of Medical Laboratory Science, College of Health Science, Dankook University, Cheonan-si, Chungnam 31116, Korea.

Tel: +82-41-550-3015, Fax: +82-41-559-7934, e-mail: hkang@dankook.ac.kr

(C) The Korean Society for Biomedical Laboratory Sciences. All rights reserved.

(C) This is an Open Access article distributed under the terms of the Creative Commons Attribution Non-Commercial License (http://creativecommons.org/licenses/by-nc/3.0/) which permits unrestricted non-commercial use, distribution, and reproduction in any medium, provided the original work is properly cited. 
적으로 $\operatorname{ROS}$ 를 제거하는데 실패할 수 있기 때문에 외부로 부터 항산화 물질을 섭취할 필요가 있다(Aischer and Hess, 1993; Wiseman, 1996).

염증은 생체 피부 등의 여러 조직에 강한 열이나 강알 칼리, 강산 등의 외부 자극원이나 조직의 손상, 감염성 병 원체의 침입 등의 다양한 원인에 의하여 유발되며 이러한 염증으로부터 인체를 보호하는 기전 중의 하나가 염증반 응이다(Kim et al., 2014; Seo et al., 2015). 어성초의 추출물은 사람의 $\mathrm{B}$ 림프구 및 $\mathrm{T}$ 림프구의 활성을 증가시키며(Chun, 1997), insulin-like growth factor (IGF)- $\gamma$ 와 lipopolysaccharide (LPS)와 같은 면역조절제에 의해 대식세포가 자극이 되었 을 경우 시토카인의 분비량을 증가시킴으로서 면역반응을 향상시킨다는 보고가 있다(Kim et al., 2005).

어성초는 삼백초과(Saururaceae)로서 학명은 Houttuynia cordata Thunb이며 다년생 초본의 야생약초로서 그늘지고 물기가 많은 곳에서 잘 자라며, 한국에서는 어성초 또는 약모밀로 불리어진다. 원산지는 한국, 중국, 일본이며, 잎 과 줄기에서 생선비린내가 난다고 하여 어성초라고 불러 지게 되었다(Kwun, 1998). 어성초의 생리활성 성분은 플 라보노이드 유도체인 quercetin, quercitrin, isoquercitrin, reynoutrin, hyperin, rutin 등과 정유 성분으로 decanoyl acetaldehyde, methyl nonylketone, laurinaldehyde, myrcene 등이 함유되어 있다(Hong and Kim, 2004). 어성초에 대한 항산 화 및 항염증에 대한 연구는 많이 알려져 있지만, 이는 어 성초 잎에 대한 연구가 대다수이며, 뿌리에 관한 연구는 크게 알려지지 않은 상황이다.

이에 본 연구에서는 생리활성 효능 검증의 일환으로 in $v i t r o$ 에서 어성초 잎과 뿌리의 에탄올 추출물의 효율과 항 산화 및 항염증에 대한 효과를 비교 검증하기 위해 연구 를 진행하였다.

\section{재료 및 방법}

\section{어성초 부위별 추출물 제조}

어성초는 경동시장에서 구입하여 잎과 뿌리를 분리하 여 $20 \mathrm{mesh}$ 이하로 조분쇄하였으며 시료 $100 \mathrm{~g}$ 에 대해 10 배의 $70 \%$ 에탄올을 넣어 추출한 후, 여과(Whatman No3, Maidstone, England)하였다. 여과한 에탄올 추출액을 감압 농축(N-1000S-WD, Eyela Co., Tokyo, Japan) 후 동결건조 (FDU-1100, Eyela Co., Tokyo, Japan)하여 에탄올 추출물을 제조하였다.

\section{총 폴리페놀 함량 측정}

어성초의 부위별 추출물의 총 폴리페놀 화합물의 함량 비교를 위해 Folin-Denis법(Folin and Denis, 1912)을 응용 하였다. 각 추출물을 농도별로 희석한 용액과 2 배 희석된 Folin 시약(Sigma Co., St. Louis, MO, USA)을 동량 첨가하 여 혼합하였다. 혼합액을 3 분간 방치한 다음 $10 \% \mathrm{Na}_{2} \mathrm{CO}_{3}$ (Sigma Co.)을 동량 넣고 1시간 반응시킨 후 UV/Visible spectrophotometer (UVIKON 922, Kontran Co., Milan, Italy) $700 \mathrm{~nm}$ 에서 흡광도를 측정하여 작성한 표준곡선으로부터 함량을 구하였다. 이 때 gallic acid (Sigma Co.)를 이용한 표 준곡선은 gallic acid의 최종농도가 $10,25,50,75,100 \mu \mathrm{g}$ $\mathrm{mL}$ 가 되도록 하여 위와 같은 방법으로 $700 \mathrm{~nm}$ 에서 흡광 도를 측정하여 구하였다.

\section{총 플라보노이드 함량 측정}

어성초 부위별 총 플라보노이드 함량은 Nieva Moreno 등(Nieva et al., 2000)의 방법을 응용하여 측정하였다. 각 샘플 $100 \mu \mathrm{L}$ 와 $80 \%$ 에탄올 $860 \mu \mathrm{L}$ 을 혼합한 혼합물에 $10 \%$ aluminium nitrate (Sigma Co.) $200 \mu \mathrm{L}$ 와 $1 \mathrm{M}$ potassium acetate (Sigma Co.) $200 \mu \mathrm{L}$ 을 혼합하고 실온에 40분 방치한 뒤 $415 \mathrm{~nm}$ 에서 흡광도를 측정하였다. 이때 총 플라보노이 드 함량은 quercetin (Sigma Co.)을 이용하여 작성한 표준곡 선으로부터 함량을 구하였다.

\section{1,1-diphenyl-2-picryl hydrazyl (DPPH) radical 소거 활성 측정}

어성초 부위별 에탄올 추출물의 free radical 소거활성은 stable radical인 DPPH (Sigma Co.)에 대한 환원력을 측정한 것으로 $99 \%$ 메탄올에 각 시료를 희석한 희석액 $160 \mu \mathrm{L}$ 와 메탄올에 녹인 $0.15 \mathrm{mM} \mathrm{DPPH}$ 용액 $40 \mu \mathrm{L}$ 를 가하여 실 온에 30 분 방치한 후 $517 \mathrm{~nm}$ 에서 흡광도를 측정하였다. $\mathrm{DPPH}$ radical 소거활성은 다음 식에 따라 소거활성을 계 산하였다.

DPPH radical scavenging activity $(\%)=[100-(\mathrm{S} / \mathrm{C} \times 100)]$

$\mathrm{S}$ : 시료군 반응 후 흡광도 - 시료군 반응 전 흡광도

$\mathrm{C}$ : 대조군 반응 후 흡광도 - 대조군 반응 전 흡광도

2,2-azino-bis (3-ethylbenzthiazoline-6-sulfonic acid (ABTS) radical 소거활성

$\mathrm{ABTS}$ radical을 이용한 항산화력 측정은 $\mathrm{ABTS}+\cdot$ cation 
decolorization assay 방법(Re et al., 1999)에 의하여 시행하였 다. $7 \mathrm{mM}$ ABTS (Sigma Co.)와 $2.45 \mathrm{mM}$ potassium persulfate (Sigma Co.)를 최종농도로 동량 혼합하여 실온인 암실에서 24시간 동안 방치하여 $\mathrm{ABTS}+$ ·을 형성시킨 후 $732 \mathrm{~nm}$ 에 서 흡광도 값이 $0.70( \pm 0.02)$ 이 되게 phosphate buffered saline (PBS, pH7.4)로 희석하였다. 희석된 용액 $20 \mu \mathrm{L}$ 에 sample $180 \mu \mathrm{L}$ 를 가하여 정확히 1 분 동안 방치한 후 흡광 도를 측정하였다.

\section{세포주 배양}

본 실험에 사용된 microglia cell line BV-2 세포는 미국 하버드의대 다나파버 암센터에서 분양받아 사용하였다. BV-2 세포는 10\% fetal bovine serum (FBS; Gibco, BRL, USA), $100 \mu \mathrm{g} / \mathrm{mL}$ penicillin (Gibco, BRL, USA) 그리고 $100 \mu \mathrm{g} / \mathrm{mL}$ streptomycin (Gibco, BRL, USA)을 첨가한 RPMI1640 배지 (Gibco, BRL, USA)를 이용하여 $5 \% \mathrm{CO}_{2}$ 가 존재하는 $37^{\circ} \mathrm{C}$ 배양기에서 2 3일에 한 번씩 계대 배양하였다.

\section{세포생존율 측정}

LPS로 자극된 BV-2 세포에서 LPS 및 어성초 부위별 추 출물이 세포 생존에 미치는 영향을 확인하기 위해 cell viability를 3-[4,5-Dimethylthiazol-2-yl]-2, 5-diphenyl-tetrazolium bromide (MTT) 분석법으로 측정하였다. 세포 $\left(4 \times 10^{4} \mathrm{cell} /\right.$ $\mathrm{mL}$ )를 96-well plate에 $100 \mu \mathrm{L}$ 씩 분주하여 12 시간 이상 $\mathrm{CO}_{2}$ 배양기에서 배양한 다음, 시료를 각각의 조건에 따 라 처리하여 24시간 배양하였다. 배양한 후 배양액을 제 거하고 $0.25 \mathrm{mg} / \mathrm{mL}$ MTT가 함유되어 있는 배지 $100 \mu \mathrm{L}$ 를 첨가한 다음 4시간 동안 배양하여 MTT가 환원되도록 하 였다. 그 후 배양액을 제거하고 dimethylsulfoxide (DMSO) $100 \mu \mathrm{L}$ 첨가하여 생성된 formazone 결정을 용해시킨 후, ELISA reader를 이용하여 $540 \mathrm{~nm}$ 에서 흡광도를 측정하였 다. 세포생존율은 대조군과 비교하여 백분율 $(\%)$ 로 나타내 었다.

\section{LPS로 활성화된 신경교세포에서 NO 생성저해 작용}

어성초 부위별 추출물의 항염증 효능을 분석하기 위하 여 본 연구에서는 염증 유발 인자인 LPS를 각 농도별로 자극된 신경교세포에서 생산되는 $\mathrm{NO}$ 농도를 의존적으로 효능을 있는지 확인하였다. NO 측정은 24 well plate에 세 포를 $4 \times 10^{4} \mathrm{cell} /$ 을 seeding한 후, LPS와 추출물을 농도차 를 두어 첨가한 후, $24 \mathrm{~h}$ incubator에서 반응시킨 후, 각각 $50 \mu \mathrm{L}$ 씩 Griess reagent (1\% sulfanilamide/0.1\% N-(1-naphthyl)-
Table 1. Total polyphenols and flavonoids contents in Leaves of Houttuynia cordata Thunb and root of Houttuynia cordata Thunb

\begin{tabular}{lccc}
\hline \hline Sample & $\begin{array}{c}\text { Extraction } \\
\text { yield } \\
(\%, \text { dry basis })\end{array}$ & $\begin{array}{c}\text { Total } \\
\text { polyphenols })^{1)} \\
(\mu \mathrm{g} / \mathrm{mg})\end{array}$ & $\begin{array}{c}\text { Total } \\
\text { flavonoids } \\
(\mu \mathrm{g} / \mathrm{mg})\end{array}$ \\
\hline Leaf & 10.08 & $59.32 \pm 2.11^{3)}$ & $10.85 \pm 0.45$ \\
Root & 9.40 & $12.07 \pm 1.03$ & $8.55 \pm 0.17$ \\
\hline
\end{tabular}

${ }^{1)}$ Milligrams of total polyphenol content/g of samples based on gallic acid as standard.

2) Milligrams of total flavonoid content/g of samples based on quercetin as standard.

3) Each value is mean \pm S.D. $(n=3)$.

ethylenediamine dihydrochloride $/ 2.5 \% \mathrm{H}_{3} \mathrm{PO}_{4}$ )와 반응시킨 후, 파장이 $540 \mathrm{~nm}$ 인 ELISA reader를 사용하여 값을 측정하 였다.

\section{결 과}

\section{추출수율}

어성초의 부위별 항산화 및 항염증 효과를 검토하기 위 하여 잎과 뿌리를 분리하여 $70 \%$ 에탄올로 추출한 후 수 율을 구하였는데, 어성초 잎과 뿌리의 에탄올 추출 수율 은 각각 $10.08,9.40 \%$ 로 어성초 잎 추출물에서 추출 수율 이 좀 더 높게 측정되었다(Table 1).

\section{폴리페놀 및 플라보노이드 함량 비교}

어성초 및 화산송이 복합 발효액에 존재하는 총 폴리페 놀 및 플라보노이드 함량은 각각 gallic acid, quercetin을 기 준물질로 하여 측정하였다(Table 1). 그 결과, 어성초 잎의 총 폴리페놀 함량은 $59.32 \mu \mathrm{g} / \mathrm{mg}$, 어성초 뿌리는 $12.07 \mu \mathrm{g} /$ $\mathrm{mg}$ 으로 나타나, 잎에서 높은 폴리페놀 함량을 보였다. 총 플라보노이드 함량은 잎과 뿌리에서 각각 $10.85,8.55 \mu \mathrm{g}$ $\mathrm{mg}$ 으로 폴리페놀 함량 경향과 유사하게 나타났다.

\section{어성초 잎 및 뿌리 추출물의 DPPH 및 ABTS free radical 소거활성}

어성초 잎과 뿌리의 항산화능을 측정하기 위해 $\mathrm{DPPH}$ 소거활성을 측정한 결과는 Fig. $1 \mathrm{~A}$ 와 같다. 각 추출물의 $\mathrm{DPPH}$ 라디칼 소거활성의 $\mathrm{RC}_{50}$ 값은 어성초 잎과 뿌리에 서 각각 $23.51,154.72 \mu \mathrm{g} / \mathrm{mL}$ 의 농도로 어성초 잎 추출물 이 약 7배 더 높은 항산화 효능을 보였다. ABTS+· 소거 활성 역시 $\mathrm{DPPH}$ 소거활성과 유사하게 잎과 뿌리 추출물 
A

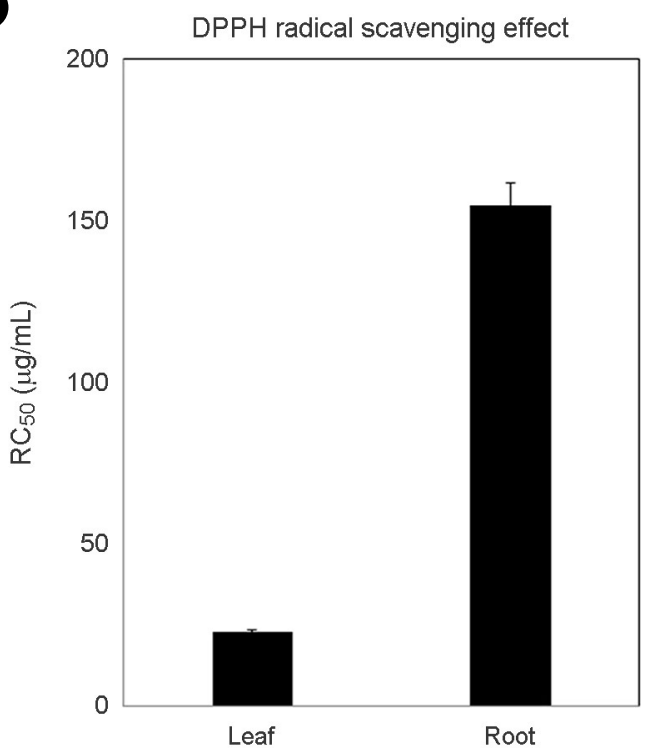

B

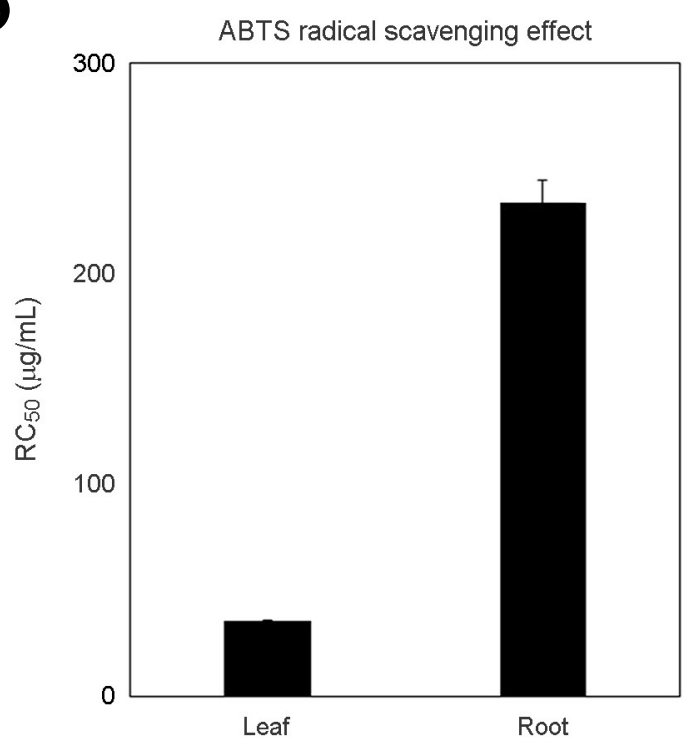

Fig. 1. DPPH (A) and ABTS (B) radical scavenging effects of Houttuynia cordata Thunb leaf and root. $\mathrm{RC}_{50}$; Extract concentrations, which show $50 \%$ activity of free radical scavenging, were determined by interpolation.

의 $\mathrm{RC}_{50}$ 값이 각각 $35.42,233.89 \mu \mathrm{g} / \mathrm{mL}$ 의 농도로 어성초 잎 추출물에서 높은 항산화 효과를 나아냈다(Fig. 1B).

\section{세포생존율 측정}

어성초 잎과 뿌리의 세포 생존에 끼치는 영향을 확인하 기 위해 BV-2 cell에 LPS, 어성초 잎 그리고 어성초 뿌리 추출물을 농도별로 처리하였다. 먼저, LPS $100 \mathrm{ng} / \mathrm{mL}$ 를 단 독으로 처리하였을 때, 대조군과 비교해서 큰 차이가 없 었다. 또한, LPS와 어성초 잎 추출물을 같이 처리하였을 때에도 cell viability가 모든 농도에서 $95 \%$ 이상으로 세포 생존에 끼치는 영향이 없었지만 어성초 뿌리 추출물에서 는 $500 \mu \mathrm{g} / \mathrm{mL}$ 의 농도에서부터 세포에 독성을 나타내는 것 을 확인하였다(Fig. 2).

\section{어성초 잎 및 뿌리 추출물의 NO 생성저해 효과}

어성초 잎과 뿌리 추출물의 항염 효과를 확인하기 위하 여 LPS로 자극하여 염증반응을 유도한 BV-2 cell에 어성 초 잎과 뿌리 추출물을 $0 \sim 2,500 \mu \mathrm{g} / \mathrm{mL}$ 의 농도별로 처리 한 후, $\mathrm{NO}$ 의 생성농도를 확인하였다. 먼저 어성초 잎 추 출물을 처리하였을 때, BV-2 cell에서 생성하는 NO의 농 도는 $200 \mu \mathrm{g} / \mathrm{mL}$ 의 농도에서부터 농도의존적으로 증가된 $\mathrm{NO}$ 농도가 감소되는 것을 확인할 수 있었다. 반면, 뿌리 추출물의 처리하였을 경우 NO 저해 효과가 나타나지 않
음을 확인하였다(Fig. 3).

\section{고 찰}

본 연구에서는 어성초 잎과 뿌리의 항산화 및 항염 효 과를 측정하여 어성초 부위별 기능을 비교 분석하고자 실 시하였다. 천연 추출물이 생리활성이 우수하여도 그 추출 수율이 낮을 경우에는 경제성이 없기 때문에 산업화에 이 용하기 어려운 부분이 있어 천연물의 추출 수율은 추후 기능성 소재 개발시 고려되어야 할 중요한 요인으로 작용 한다. 천연 추출물의 수율이 $10 \%$ 이상일 경우 산업화시 경제성이 있는 것으로 보고(Park et al., 2003)되었는데, 본 연구 결과 어성초 잎 추출물에서 $10 \%$ 이상의 수율을 보 여 추후 산업화 소재로 적합한 소재라 할 수 있다.

항산화 효과와 같은 생리활성을 나타낼 수 있는 성분으 로는 비타민 및 폴리페놀류를 들 수 있으며, 이러한 폴리 페놀류는 천연에 존재하는 여러 식용 및 약용식물에 분포 되어 있다. 폴리페놀류들은 수용성으로 플라보노이드류가 대부분을 차지하고 있다(Huang et al., 1992). 특히 플라보노 이드류는 암세포의 DNA, RNA, protein의 합성을 억제 또 는 $\mathrm{cAMP}$ 의 농도를 증가시킴으로써 종양세포의 분열을 억제하거나 apoptosis를 유도하는 등의 다각적 기전을 통 해 항암 효과를 발휘하는 것으로 알려져 있다(Suolinna et 


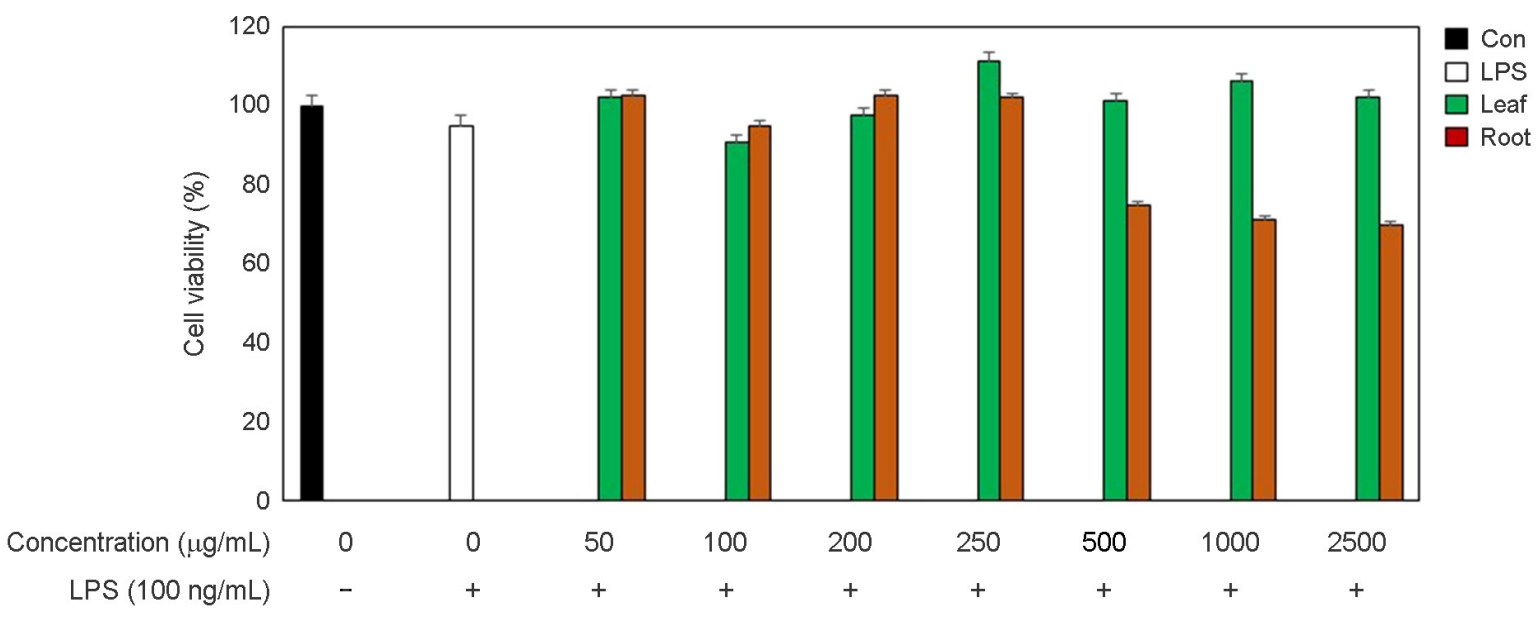

Fig. 2. Effect of Houttuynia cordata Thunb leaf and root on cytotoxicity in BV-2 cells. Houttuynia cordata Thunb leaf and root was treated with various concentrations in BV-2 cells for $24 \mathrm{~h}$. Values are expressed as the mean $\pm \mathrm{SD}(\mathrm{n}=3)$ of determinations made in triplicate experiments.

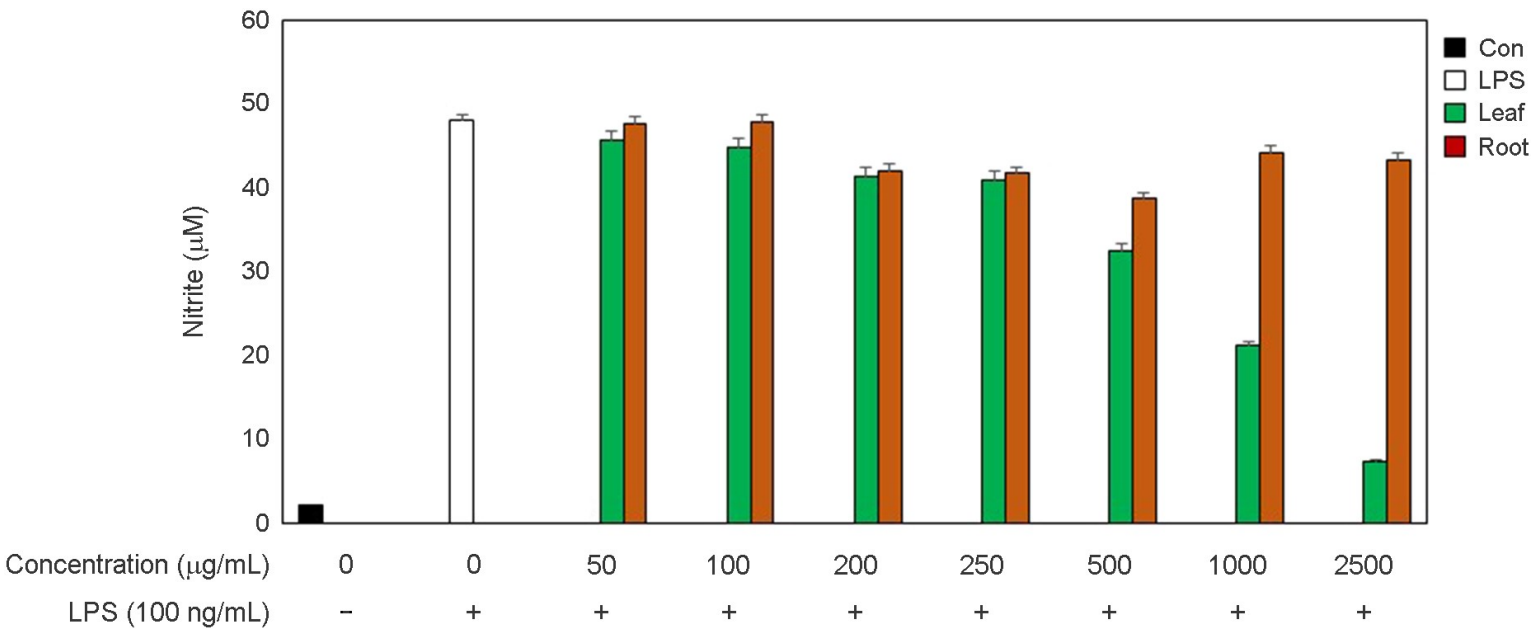

Fig. 3. Effect of Houttuynia cordata Thunb leaf and root on NO production in BV-2 cells. Houttuynia cordata Thunb leaf and root was treated with various concentrations in BV-2 cells for $24 \mathrm{~h}$. Values are expressed as the mean $\pm \mathrm{SD}(\mathrm{n}=3)$ of determinations made in triplicate experiments.

al., 1975; Gerriten, 1995). 천연항산화제의 역할을 하는 폴리 페놀과 플라보노이드 햠랑을 측정한 결과, 어성초 잎 추 출물에서 뿌리보다 높은 함량을 나타냈다(Table 1).

$\mathrm{DPPH}$ 는 천연 추출물의 항산화 활성 측정에 이용되고 있는 대표적인 radical로 짙은 자색을 띄는 비교적 안정한 free radical로서 항산화제, 방향족 아민류 등에 의해 환원 되어 색이 탈색되는 것을 이용하여 항산화 물질을 검색하 는데 이용되고 있다. 또한, ABTS+· 소거활성은 청록색으 로 탈색된 free radical의 제거 정도를 흡광도 값으로 나타 내어 $\mathrm{ABTS}+$ ·의 소거 활성능을 측정할 수 있고 탈색반응
이 1 분 안에 종료되어 단시간에 측정 가능하다. 어성초 잎 과 뿌리 추출물의 $\mathrm{DPPH}$ 와 $\mathrm{ABTS}$ 라디칼 소거능은 폴리 페놀 및 플라보노이드 함량의 경향과 유사하여 잎 추출 물에서 뿌리 추출물보다 높은 라디칼 소거능을 나타내는 것을 확인하였다(Fig. 1).

$\mathrm{NO}$ 는 NOS 에 의해 L-arginine으로부터 생성된다. iNOS 는 세균의 내독소 및 염증성 사이토카인에 의해 강하게 유도된다(Guha and Mackman, 2001). 병리적인 조건 하에 서 $\mathrm{iNOS}$ 에 의한 $\mathrm{NO}$ 의 현저한 증가는 다른 염증성 매개 체들과 함께 과도한 염증을 유발하게 되고 조직의 손상을 
유발하는 것으로 알려져 있어 염증성 손상의 주요 매개체 이다(Nathan, 1992). 따라서 iNOS의 발현 또는 활성을 억 제함으로써 $\mathrm{NO}$ 의 생성을 억제할 수 있는 화합물은 항염 증 물질로 이용될 수 있을 것이다. 이에 어성초 잎과 뿌리 추출물이 $\mathrm{NO}$ 의 생성을 저해할 수 있는지를 알아본 결과 Fig. 3 과 같이 나타났다. $\mathrm{NO}$ 생성저해 효과를 측정하기 전 에 어성초 잎과 뿌리 추출물이 세포에 독성을 나타내는지 를 MTT assay를 이용하여 측정하였을 때, 어성초 뿌리 추 출물의 $500 \mu \mathrm{g} / \mathrm{mL}$ 농도에서부터 세포독성을 확인하였다 (Fig. 2). LPS만 처리한 군에서는 NO가 약 $48.2 \mu \mathrm{M}$ 로 처리 하지 않은 군보다 약 23배 이상의 $\mathrm{NO}$ 를 생성하였고 여기 에 어성초 잎과 뿌리 추출물을 처리한 군의 경우 잎 추출 물 처리군에서 농도에 따라 $\mathrm{NO}$ 생성이 감소되는 것을 확 인하였다(Fig. 3). 이는 폴리페놀 및 플라보노이드 함량과 라디칼 소거능이 어성초 잎 추출물에서 더 우수하게 나타 난 결과와 일치하는 결과를 보여 주었다.

이상의 결과로 어성초의 부위 중 잎 부분이 다량의 기 능성 성분을 함유하고 있음을 확인하였고, 이에 우수한 항산화 및 항염증 효능을 나타내는 것으로 생각되며 이러 한 결과를 바탕으로 어성초 잎 추출물의 여러 생리활성 물질 및 기능들에 관한 연구를 통해 기능성 식품 소재로 활용될 수 있을 것으로 기대된다.

\section{ACKNOWLEDGEMENTS}

This work was supported by the National Research Foundation of Korea (NRF) grant funded by the Korea government (MOE) (No. NRF-2016R1A6A3A11935472).

\section{CONFLICT OF INTEREST}

The authors have no conflicts of interest to disclose.

\section{REFERENCES}

Aischer RG, Hess JL. Antioxidants in higher plants. CRC Press, Boca Raton. 1993. 1-17.

Bouayed J, Bohn T. Exogenous antioxidants-Double-edged swords in cellular redox state: Health beneficial effects at physiologic doses versus deleterious effects at high doses. Oxidative Medicine and Cellular Longevity. 2010. 3: 228-237.

Chen L, Hu JU, Wang SQ. The role of antioxdants in photoprotection: A critical review. Journal of the American Academy of Dermatology. 2012. 67: 1013-1024.

Chun EY. Partial purification of Houttuynia cordata Thunb extract and characterization of its immunological activities in human. MS Thesis, Seoul National University. 1997.

Decker EA, Crum AD, Calvert JT. Differences in the antioxidant mechanism of carmosine in the prescence of copper and iron. Journal Of Agricultural And Food Chemistry. 1992. 40: 756 -759 .

Folin O, Denis W. On phosphotungstic-phosphomolybdic compounds as color reagents. The Journal of Biological Chemistry. 1912. 12: 239-249.

Gerriten ME. Flavonoids inhibit cytokine-induced endothelial cell adhesion protein gene expression. American Journal of Pathology. 1995. 147: 278-292.

Guha M, Mackman N. LPS induction of gene expression in human monocytes. Cell signal. 2001. 13: 85-94.

Huang MT, Ho CT, Lee CY. Phenolic compounds in food. In phenolic compounds in food and their effects on health II. New York: Maple Press. 1992. 2-7.

Hong ND, Kim NJ. Quality control of herbal medicines. Shinil Books, Seoul, Korea. 2004. 476-477.

Kim B, Kim JI, Kim HR, Byun DS. Anti-inflammatory effect of an ethyl acetate fraction from Myagropsis yendoi on lipopolysaccharides-stimulated RAW 264.7 cells. Korean Journal of Fisheries and Aquatic Sciences. 2014. 47: 527-536.

Kim J, Ryu HS, Shin JH Kim HS. In vitro and ex vivo supplementation of Houttuynia cordata extract and immunomodulating effect in mice. Journal of the Korean Society of Food Science and Nutrition. 2005. 34: 167-175.

Kwun JA. About Houttuynia cordata Thunb. Korean Oriental Drug. 1998. 2: 218-221.

Nathan C. Nitric oxide as a secretory product of mammalian cells. The FASEB Journal. 1992. 6: 3051-3064.

Nieva, Moreno MI, Isla MI, Sampietro AR, Vattuone MA. Comparison of the free radical-scavenging activity of propolis from several regions of Argentina. Journal of Ethnopharmacology. 2000. 71: 109-114.

Park SH, Lim HY, Han JH. A study of medicinal herbs for func0 tional food application (I) Nutritional composition and scopolectin analysis of Artemisia capilaries. The East Asian Society Of Dietary Life. 2003. 13: 552-560.

Re R, Pellegrini N, Proteggente A, Pannala A, Yang M, Rice-Evans C. Antioxidant activity applying an improved ABTS radical cation decolorization assay. Free Radical Biology and Medicine. 1999. 26: 1231-1237.

Seo DW, Yi YJ, Lee MS, Yun BS, Lee SM. Differential modulation of lipopolysaccharide nduced inflammatory cytokine produc- 
tion by and antioxidant activity of fomentariol in RAW264.7 cells. Mycobiology. 2015. 43: 450-457.

Suolinna EM, Buchsbaum RN, Racker E. The effect of flavonoids on aerobic glycolysis and growth of tumor cells. Cancer Research. 1975. 35: 1865-1872.

Tanaka H, Dinenno FA, Monahan KD, Clevenger CM, DeSouza

CA, Seals DR. Aging, habitual exercise, and dynamic arterial compliance. Circulation. 2000. 102: 1270-1275.

Wiseman H. Dietary influences on membrane function: impotent in protection against oxidative damage and disease. The Journal of Nutritional Biochemistry. 1996. 7: 2-15

https://doi.org/10.15616/BSL.2018.24.2.87

Cite this article as: Lee SG, Kang $\mathrm{H}$. Effects of Houttuynia cordata Extracts of Different Aerial Parts on Antioxidants and Anti-inflammatory. Biomedical Science Letters. 2018. 24: 87-93. 